\title{
Pencegahan Dampak Lingkungan Pada Industri Pewarnaan Melalui Pendekatan Penilaian Siklus Daur Produk
}

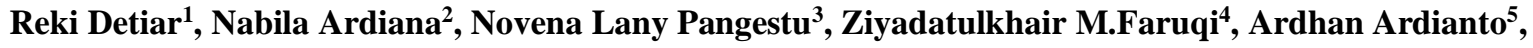 \\ Nurulbaiti Listyendah Zahra ${ }^{6}$, I Wayan Koko Suryawan ${ }^{7 *}$ \\ 1,2,3,4,5,6,7 Program Studi Teknik Lingkungan Universitas Pertamina, Teuku Nyak Arief, Jakarta 12220, Indonesia \\ *Koresponden email: i.suryawan@universitaspertamina.ac.id
}

Diterima: 15 Mei 2021

Disetujui: 28 Mei 2021

\begin{abstract}
The home-scale coloring industry is currently starting to develop with various models and effects which result in the production of various phases of solid, liquid, and gas emissions. The purpose of this study is to measure the environmental impact and ensure that life management minimizes the impact of recycling industrialdye. This research was conducted by direct industry observation methods and a literature review on the management of industrial waste. Environmental impact calculations were completed carried out using the 2018 Environmental Product Declaration (EPD) method on SimaPro 9.1.1 with an ecoinvent 3 database. The results of the environmental impact assessment should be managed according to the effects of water scarcity, acidification, and eutrophication. Pollution prevention can occur by treating industrial wastewater dye. Wastewater treatment can be performed by biological processes based on the biodegradability index. The biodegradability index of 0.3 indicates that wastewater can be treated by the activated sludge process and by moving the bed biofilm reactor (MBBR).
\end{abstract}

Keywords: environmental impact, product life cycle, staining, wastewater, staining waste management,

\begin{abstract}
Abstrak
Industri pewarnaan dengan skala rumahan saat ini sudah mulai berkembang dengan berbagai model dan efek yang mengakibatkan kegiatan tersebut menghasilkan berbagai fase limbah padat, cair, dan emisi gas. Tujuan dari studi ini adalah untuk mengetahui dampak lingkungan dan membuat upaya minimalisasi dampak dengan penilaian daur hidup produk industri pewarnaan, Penelitian ini dilakukan dengan metode observasi langsung ke industri dan mempelajari studi literatur mengenai pengelolaan limbah industri pewarnaan. Perhitungan dampak lingkungan dilakukan dengan metode Environmental Product Declaration (EPD) 2018 pada SimaPro 9.1.1 dengan database ecoinvent 3. Hasil analisa dampak lingkungan memperlihatkan perlu dilakukannya pengelolaan pada dampak water scarcity, acidification, dan eutrophication. Pencegahan pencemaran dapat dilakukan dengan pengolahan air limbah industri pewarnaan. Pengolahan air limbah dapat dilakukan dengan proses biologis dengan memperhatikan indeks biodegradabilitas. Indeks biodegradabilitas di atas 0,3 menunjukkan air limbah dapat diolah dengan proses activated sludge dan moving bad biofilm reactor (MBBR).

Kata kunci: dampak lingkungan, daur hidup produk, pewarnaan, air limbah, pengelolaan limbah pewarnaan
\end{abstract}

\section{Pendahuluan}

Kemajuan ekonomi di Indonesia saat ini dipengaruhi oleh kegiatan industri. Era industri dapat mempengaruhi urbanisasi serta peningkatan standar hidup masyarakat saat ini. Sebab itu, kegiatan industri mempengaruhi limbah yang dihasilkan dari kegiatan industri, sehingga dapat menyebabkan masalah serius dalam mencemari lingkungan [1]. Limbah industri merupakan persoalan serius dalam pengelolaan lingkungan di Indonesia. Sebab itu, pengaruh ramah lingkungan untuk industri menjadi isu penting dan menjadi alasan penting untuk menciptakan perkembangan berkelanjutan [2]. Artinya, industri tersebut harus memiliki pengelolaan limbah yang baik dari hulu hingga hilir proses kegiatan industri. Setiap industri dapat menghasilkan limbah berupa limbah padat, gas, dan cair. Pengelolaan limbah berupa gas, padat, dan cair, diperlukan untuk pencapaian kondisi lingkungan yang baik [3].

Pengelolaan limbah disuatu industri dapat dibagi menjadi pengelolaan air limbah, pengelolaan limbah padat, dan pengendalian emisi gas. Tujuan dalam pengelolaan air limbah industri tekstil adalah menghilangkan parameter fisik, kimia, biologi, hingga mikro polutan agar memenuhi baku mutu yang telah dibuat oleh pemerintah [4]. Industri pewarnaan merupakan salah satu industri yang membutuhkan air 
dengan jumlah yang sangat besar. Sifat air limbah pewarnaan mengandung garam yang tinggi karena penggunaan deterjen yang substansial mengurangi konduktivitas hidrolik sistem tanah ketika dibuang tanpa diolah. Secara global, masalah lingkungan yang terkait dengan industri tekstil adalah itu terkait dengan pencemaran air yang disebabkan oleh langsung pembuangan limbah yang tidak diolah dan pelepasan racun bahan kimia ke badan air. Kondisi ini secara drastis menurunkan konsentrasi oksigen di badan air karena adanya hidrosulfida dan menghalangi jalannya cahaya melalui badan air yang merugikan ke ekosistem air.

Peningkatan kualitas lingkungan dapat dilakukan dengan melakukan upaya penilaian siklus produk agar dapat melakukan upaya minimasi limbah. Penilaian siklus adalah salah satu alat yang dapat digunakan untuk mengklarifikasi pertanyaan-pertanyaan untuk produk dan proses, serta untuk menilai potensi dampak lingkungan [5]. Evaluasi siklus hidup produk adalah studi awal hingga akhir, digunakan untuk menganalisis dan mengevaluasi dampak produk terhadap lingkungan dan manusia selama semua atau tahap siklus hidupnya [6]. Penilaian siklus hidup produk berfokus pada dampak kelestarian lingkungan seperti energi, air, dan konsumsi material selama pembuatan dan penggunaan produk yang mengandung partikel nano. Penilaian siklus hidup produk memungkinkan pemisahan dampak menjadi beberapa kategori, seperti global warming potential, water scarcity, acidification, eutrophication, dan lain-lain [7] [8].

Setelah mengetahui kuantifikasi data dampak yang paling berpotensi mencemari lingkungan maka dapat dilakukan rekomendasi melalui interpretasi data [9]. Tujuan dari penelitian ini adalah untuk mengidentifikasi dampak lingkungan siklus hidup produk proses pewarnaan Industri X dan memberikan rekomendasi pengelolaan limbah dari dampak penting.

\section{Metode Penelitian}

Penelitian ini dilakukan dengan melakukan survei langsung ke lokasi industri pewarnaan. Survei dilakukan untuk mengetahui siklus dari pewarnaan pakaian celana dari tahap awal sampai tahap finishing produk. Survei dilakukan di salah satu industri pewarnaan skala rumah tangga di wilayah Jakarta Selatan pada bulan September - November 2019 dengan wawancara secara lisan. Analisa setiap siklus dan dampak lingkungan dilakukan dengan studi literatur yang berkaitan dengan produksi limbah industri pewarnaan.

Penilaian siklus hidup dalam pekerjaan ini dilakukan dengan menggunakan perangkat lunak SimaPro 9.1.1, yang dikembangkan oleh PRé Sustainability sebagai platform pemodelan LCA yang sesuai. Ini disediakan dengan database Ecoinvent v.3 dengan beberapa proses unit, metode analisis, dan alat. Sedangkan untuk analisa dapat dilakukan dengan metode Environmental Product Declaration (EPD) 2018. Hasil perhitungan tersebut kemudian dievaluasi berdasarkan kajian literatur yang berhubungan dengan pengelolaan limbah industri pewarnaan.

\section{Hasil dan Pembahasan}

Industri X merupakan industri rumahan yang termasuk ke dalam industri pewarnaan tekstil, terkhusus kepada celana. Proses bisnis industri ini hanya berfokus pada pencucian dan pewarnaan pakaian, terdapat juga kegiatan handmade atau memberikan model atau efek terhadap celana. Namun, kegiatan handmade merupakan kegiatan yang bersifat opsional, dilakukan sesuai dengan permintaan pelanggan

\section{Tahapan Proses dalam Industri $X$ Penggelantangan (Bleaching)}

Pada Industri X, proses bleaching merupakan alur tahapan proses yang berbeda dengan proses pemberian warna (dyeing) karena bertujuan untuk menurunkan warna atau menghilangkan pigmen alam yang terdapat pada serat pakaian sehingga warna pakaian menjadi putih. Proses ini dilakukan setelah penghilangan kanji. Bleaching dilakukan dengan merendam pakaian dalam larutan air dan hipoklorit $\left(\mathrm{ClO}^{-}\right.$ ) selama $10-30$ menit pada suhu $60^{\circ} \mathrm{C}$. Air yang digunakan sebesar 400 liter dan jumlah hipoklorit yang dimasukkan berada pada rentang $15-30 \mathrm{~kg}$.

\section{Pewarnaan (Dyeing)}

Pada tahap ini, selain diberikan zat warna sesuai dengan hasil warna yang diinginkan, ditambahkan pula air sebanyak 400 liter pada suhu $70^{\circ} \mathrm{C}$ selama 40 menit. Setelah kandungan kanji pada kain dihilangkan, dilakukan pemberian warna secara merata pada kain. Pewarna yang digunakan adalah zat pewarna sintesis direct. Komposisi pewarna ini terdiri dari 87\% azo tanpa logam, 5\% azo kompleks logam, $5 \%$ stilben, oksazin 1\%, dan zat lainnya $1 \%$ [10]. Pertimbangan penggunaan pewarna direct adalah harga yang relatif murah. Jenis zat warna yang digunakan di Industri $\mathrm{X}$ berbeda-beda tergantung warna yang akan dihasilkan. 


\section{Pemerasan/Pengeringan (Pressing/Drying) dan finishing}

Tahap ini merupakan tahap akhir yang dilakukan oleh industri X. Pada tahap ini, pakaian setengah kering yang telah dihilangkan kadar airnya dikeringkan dalam mesin oven selama 40 menit - 1,5 jam dengan suhu mencapai mencapai $70^{\circ} \mathrm{C}$. Setelah pakaian tersebut kering, kemudian dilipat dan diserahkan kepada industri tekstil finishing untuk dilakukan proses penyempurnaan. Tahap ini penggunaan energi listrik menjadi sangat penting karena menghasilkan emisi $\mathrm{CO}_{2}$ dari mesin pengering. Selain mesin cuci, mesin pengering membutuhkan daya listrik yang besar [11]. Perbandingan dengan proses lainnya proses ini menyumbangkan energi listrik lebih besar. Di fasilitas pewarnaan hotel proses pengeringan dapat mengkonsumsi listrik sebesar 65\% [12].

\section{Penilaian Siklus Hidup Produk}

Penilaian siklus hidup produk dari industri pewarnaan dibagi menjadi tiga tahap yaitu penggelantangan (bleaching), pewarnaan (dyeing), dan pemerasan/pengeringan (pressing/drying). Dari ketiga proses tersebut proses pewarnaan merupakan tahapan proses yang menyumbangkan dampak lingkungan terbesar yaitu sekitar 69,9\% (Gambar 1). Menurut Ref. [13] dampak lingkungan utama datang dari proses pencelupan warna, dimana polutan utama dalam limbah adalah padatan tersuspensi tinggi, COD, warna, air panas, keasaman dan zat terlarut lainnya. Pewarna bisa tetap berada di lingkungan selama jangka waktu yang diperpanjang karena termal tinggi dan stabilitas foto untuk menahan biodegradasi. Lebih besar perhatian lingkungan dengan pewarna adalah penyerapannya dan pantulan sinar matahari memasuki air [14]. Penyerapan mengurangi aktivitas fotosintesis alga dan mempengaruhi rantai makanan. Pewarna tekstil konsentrasi tinggi di badan air menghentikan kapasitas reoksigenasi air penerima dan memutus sinar matahari, sehingga mengganggu aktivitas biologis dalam kehidupan akuatik dan juga proses fotosintesis tumbuhan air atau alga [15].

Berdasarkan skor nilai dampak pada analisa daur siklus produk industri pewarnaan (Tabel 1) yang telah dilakukan terdapat dampak yang menjadi perhatian utama yaitu water scarcity, asidifikasi, dan eutrofikasi. Kementerian Pekerjaan Umum dan Perumahan Indonesia telah memprediksikan bahwa permukaan air di Jawa akan turun menjadi $476 \mathrm{~m}^{3}$ per orang per tahun pada tahun 2040 [16]. Ini dikategorikan sebagai "kelangkaan total" dan jauh di bawah tingkat tahunan saat ini yaitu $1.169 \mathrm{~m}^{3}$ per kapita. Kementerian mengatakan jumlah air per kapita yang ideal adalah $1600 \mathrm{~m}^{3}$ per tahun [16]. Walaupun global warming memiliki total nilai sebesar $527 \mathrm{~kg} \mathrm{CO}$ eq akan tetapi dampak global warming tidak langsung dirasakan oleh manusia dibandingkan dengan penurunan sumber daya air dan eutrofikasi. Dampak lingkungan dari proses pewarnaan di Indonesia harus menjadi perhatian adalah tercemarnya badan air di sekitar kawasan industri dan padat penduduk karena kandungan tingginya kandungan nutrien [17] [18]. Kemunculan kembali dari pertumbuhan alga beracun telah meningkat di air permukaan Kota Jakarta karana adanya nutrient [19] [20] [21]. Karena dampak yang ditimbulkan dari tumbuhnya alga beracun langsung ke kesehatan manusia maka pencegahan munculnya dampak eutrofikasi harus dari sumber limbah dimana salah satunya adalah industri pewarnaan.

Aspek air limbah menjadi parameter penting dalam pengelolaan limbah industri pewarnaan. Tahapan awal dalam memilih metode pengolahan untuk air limbah digunakan perbandingan BOD/COD. Apabila nilai dari perbandingan tersebut $>0,3$ maka dapat dilakukan pengolahan secara biologis. Akan tetapi, apabila nilai perbandingannya $<0,3$ maka harus dilakukan pengolahan secara kimia [22].

Tabel 1. Penilaian dampak lingkungan yang dihasilkan dari industri pewarnaan

\begin{tabular}{lrl}
\hline Kategori Dampak Lingkungan & \multicolumn{1}{c}{ Total } & \multicolumn{1}{c}{ Unit } \\
\hline Global warming & 527 & $\mathrm{~kg} \mathrm{CO}_{2} \mathrm{eq}$ \\
Water Scarcity & 341 & $\mathrm{~m}^{3} \mathrm{eq}$ \\
Acidification (fate does not include.) & 1,93 & $\mathrm{~kg} \mathrm{SO}_{2} \mathrm{eq}$ \\
Eutrophication & 0,752 & $\mathrm{~kg} \mathrm{PO}_{4}^{---\mathrm{eq}}$ \\
Ozone layer depletion & 0.0000512 & $\mathrm{~kg} \mathrm{CFC}^{-11} \mathrm{eq}$ \\
\hline
\end{tabular}

Sumber: Hasil perhitungan software Simapro 9.1.1 


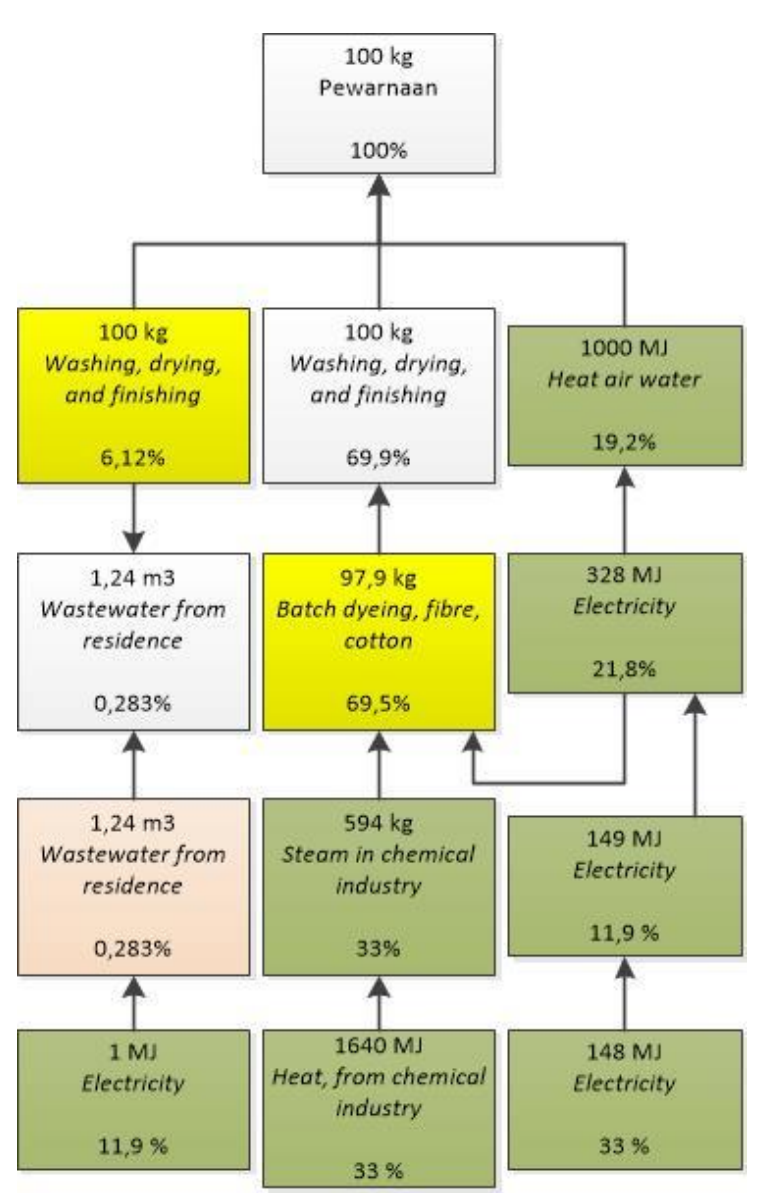

Gambar 1. Diagram alir proses penggunaan material pada industri pewarnaan yang digunakan setiap hari Sumber: Hasil perhitungan dan modifikasi dengan software Simapro 9.1.1

\section{Pencegahan Pencemaran}

Industri tekstil merupakan industri yang dapat menghasilkan berbagai macam limbah seperti limbah padat, cair maupun gas sehingga apabila tidak dikelola secara benar dapat menyebabkan terjadinya pencemaran lingkungan. Pada kondisi eksisting yang ada di Industri $X$, saat ini belum dilakukan pengelolaan lingkungan dengan baik dan bertanggung jawab terhadap limbahnya. Dengan diberlakukannya regulasi tersebut, maka air limbah yang bersumber dari usaha dan/atau kegiatan industri tekstil perlu diterapkan baku mutu air limbah sebelum dibuang ke media air, pengelolaan lingkungan dengan baik dan tepat guna serta upaya-upaya pencegahan pencemaran dan minimasi limbah dengan pendekatan produksi bersih. Upaya pencegahan pencemaran dan minimasi limbah secara umum memiliki urutan tahapan [23], yang ditunjukkan pada Gambar 2.

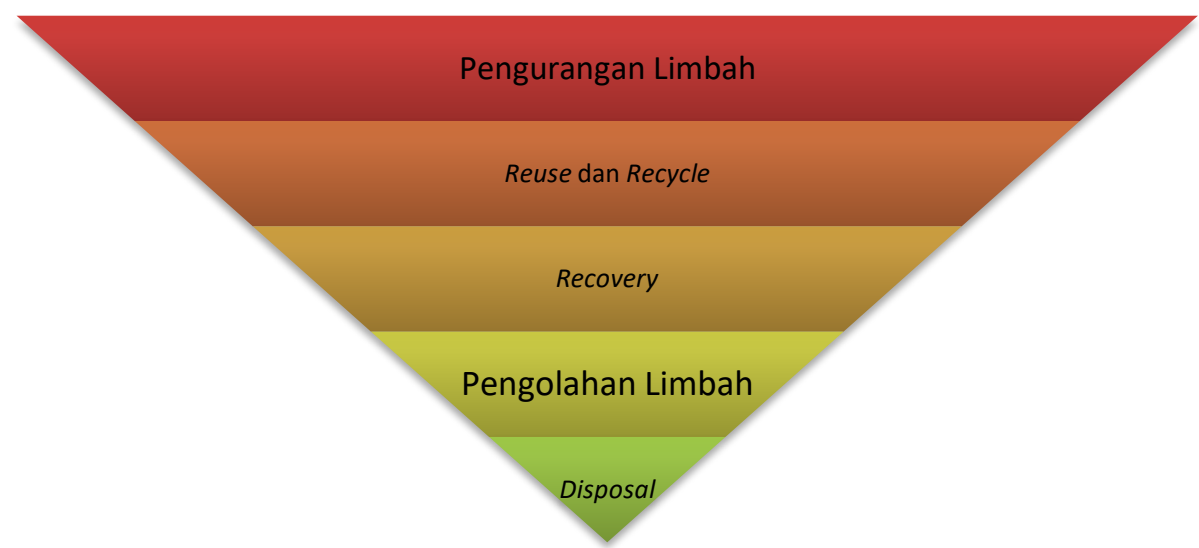

Gambar 2. Tahapan prioritas upaya pencegahan dan minimasi limbah Sumber: Ref. [23] 
Dalam memenuhi baku mutu dari air limbah yang dihasilkan, dibutuhkan pengolahan yang efektif dalam mengolah air limbah tersebut. Akan tetapi tak hanya peningkatan baku mutu pengolahan air limbah saat ini harus lebih proaktif sehingga air limbah dapat digunakan kembali untuk memenuhi kebutuhan manusia [24][25]. Ini artinya industri dapat menggunakan kembali sumber daya yang berpotensi menjadi limbah. Penggunaan kembali air limbah merupakan salah satu cara mendukung hal tersebut. Beberapa teknologi pengolahan air limbah lanjutan dapat meningkatkan hal tersebut [26][27]. Beberapa penelitian mengusulkan penggunaan teknologi membrane dalam pengolahan air limbah pewarnaan dan sangat efektif dalam penyisihan parameter polutan [28][29]. Akan tetapi pengolahan dengan teknologi membran membutuhkan biaya operasional dan perbaikan yang mahal [30]. Pengolahan dengan memanfaatkan mikroorganisme merupakan salah satu pilihan untuk mengolah limbah dengan biaya yang relatif murah. Untuk mengoperasikan pengolahan biologis dapat dilakukan perlu dilakukan uji karakteristik limbah terlebih dahulu dengan memperhatikan nilai BOD/COD agar melebihi 0,3. Jika nilai BOD/COD tidak memenuhi kriteria tersebut sangat perlu dilakukan pengolahan pendahuluan untuk meningkatkan nilai BOD/COD menjadi lebih dari 0,3. Pengolahan untuk meningkatkan BOD/COD seperti ozonisasi ataupun Advanced Oxidation Process (AOP) [30] [31] [32][33].

Tiga metode pengolahan air limbah secara biologis yang dapat digunakan. Melihat dapat tidaknya air limbah pewarnaan diolah dengan proses biologis dapat dilihat dengan nilai perbandingan Biological Oxygen Demand (BOD) dengan Chemical Oxygen Demand (COD). Penelitian karakteristik air limbah yang mengandung wana reaktif memiliki indeks biodegradabilitas sebesar 0.056 [35] dan bahkan hanya memiliki indeks sebesar 0 [36]. Sebagai upaya peningkatan biodegradabilitas air limbah industri pewarnaan, pengolahan ozonisasi ataupun Advanced Oxidation Process (AOP) perlu diaplikasikan terlebih dahulu. Setelah dilakukan pre-treatment, juga perlu dilakukan proses seeding dan aklimatisasi atau penyesuaian kembali mikroorganisme dalam air limbah yang sudah diolah [36]. Terdapat dua jenis pengolahan limbah pewarnaan berbasis biologis yang dapat diaplikasikan di industri pewarnaan yaitu dengan proses activated sludge dan moving bad biofilm reactor (MBBR).

Activated sludge merupkan pengolahan air limbah yang memanfaatkan proses mikrobiologi yang tersuspensi. Dengan bantuan udara yang disalurkan melalui pipa blower agar terjadi proses aerobik. Sel mikroba akan membentuk flok yang akan mengendap dalam tangki penjernihan. Activated sludge sudah banyak diaplikasikan dalam beberapa penelitian dan memiliki potensi yang tidak cukup baik [37]. Saat ini lumpur teknologi lumpur aktif harus didahului dengan teknologi oksidator kuat untuk meningkatkan biodegradabilitas sehingga efisiensi penyisihan bahan organik dapat mencapai efisiensi yang optimum [33]. Penyisihan BOD pada limbah pewarnaan dapat mencapai 97,18 \% dengan waktu detensi selama 24 jam [38]. Kelebihan teknologi MBBR membutuhkan lahan yang relatif lebih kecil, tidak ada endapan lumpur, konsentrasi biomassa tinggi, toleransi terhadap perubahan beban organik, efisiensi COD yang tinggi, dan tidak perlu adanya pencucian berkala [39]. Pengolahan dengan cara MBBR dapat menyisihkan COD sebesar $90 \pm 1 \%$ dan penyisihan ammonium sebesar 97 $\pm 2 \%$ [40]. Penelitian lain menyebutkan penyisihan warna dengan sistem hybrid ozone pre-treatment dan MBBR dapat menyisihkan COD 96,9\% dan warna sebesar $86,74 \%$ [41].

\section{Kesimpulan}

Berdasarkan analisis dampak lingkungan daur produk yang telah dilakukan di industri pewarnaan X menyebutkan aspek lingkungan yang berpotensi menimbulkan dampak penting adalah air limbah. Untuk itu perlu dilakukan upaya minimasi air limbah atau penambahan teknologi. Sebelum dilakukan pengolahan diperlukan analisa terhadap nilai biodegradabilitas air limbah. Jika nilai biodegradabilitas diatas 0,3 maka pengolahan air limbah yang dapat diterapkan pada industri pewarnaan X adalah Activated Sludge dan Moving Bad Biofilm Reactor (MBBR). Sedangkan jika biodegradabilitas masih dibawah 0,3 maka perlu dilakukan pengolahan pendahuluan seperti ozonisasi.

\section{Referensi}

[1] G. Sandin, and G. M. Peters, "Environmental impact of textile reuse and recycling-A review," J. of cleaner production, Vol. 184, pp. 353-365, 2018.

[2] M. Nasir, E. P. Saputro, and S. Handayani, "Manajemen Pengelolaan Limbah Industry," Benefit: J. Manajemen dan Bisnis, 19(2), 143-149, 2016.

[3] S. Wu and J. Fan, "Study on the environmental effects of electronic information industry in Anhui province based on metering model of industrial waste gas, wastewater and waste," Chemical Engineering Transactions, 59, 1159-1164, 2017. 
[4] I. Suryawan, M. J. Siregar, G. Prajati, and A. S. Afifah, "Integrated ozone and anoxic-aerobic activated sludge reactor for endek (Balinese textile) wastewater treatment," J. of Ecological Engineering, 20(7), 2019.

[5] EPA; TRACI. Available online: https://www.epa.gov/chemical-research/tool-reduction-andassessment-chemicals-andother-environmental-impacts-traci (accessed on 15 December 2019).

[6] I. M. Krishna, V. Manickam, A. Shah, and N. Davergave, Environmental management: science and engineering for industry, Butterworth-Heinemann, 2017.

[7] M. Nurhayati, T. Djatna, and I. G. Permana, "Kinerja rantai pasok dan nilai tambah dengan internalisasi aspek lingkungan pada agroindustri ayam ras pedaging," J. of Agroindustrial Technology, 26(3), 2016.

[8] J. S. Adiansyah, N. P. Ningrum, D. Pratiwi, and H. Hadiyanto, "Kajian Daur Hidup (Life Cycle Assessment) dalam Produksi Pupuk Urea: Studi Kasus PT Pupuk Kujang,” J. Ilmu Lingkungan, Vol. 17(3), hal. 522-527, 2018.

[9] I. W. K. Suryawan, A. Rahman, I.Y. Septiariva, S. Suhardono, and I. M. W. Wijaya, "Life Cycle Assessment of Solid Waste Generation During And Before Pandemic of Covid-19 In Bali Province," J. of Sustainability Science and Management, Vol. 16(1), pp. 11-21, 2012.

[10] Kuntadi, E.W. Laksono, "Isoterm Adsorpsi Dari Adsorben Nata De Ipomoea Pada Adsorpsi Pewarna Direct Red Teknis," J. Kim Dasar, 5(6):1-9, 2016.

[11] M. I. Maulana, and M. A. Muslim, "Sistem Prediksi Tagihan Listrik Usaha Jasa Laundry Menggunakan Jaringan Syaraf Tiruan Backpropagation,” Unnes J. of Mathematics, 4(1), 2016.

[12] J. Pramono, "Studi Sekunder Terhadap Pengelolaan Lingkungan Pada Hotel Berbintang Di Sebuah Destinasi," Call Pap Semin Nas Has Penelit At Tegaljaya, Badung, Bali [Internet]. 2012; Available from: https://www.researchgate.net/publication/30384219

[13] S. M. Imtiazuddin, S. Tiki, and A. V. M. Chemicals, "Impact of Textile Waste Water Pollution on the Environment," Pakistan Textile J., 10, 38-39, 2018.

[14] A. S. Afifah, Y. Adicita, and I. Suryawan, "Reduksi Warna Methylen Blue (MB) dengan Granular Zeolit Klinoptilolit Teraktivasi," Media Ilmiah Teknik Lingkungan (MITL), 6(1), 24-33, 2021.

[15] S. Gita, A. Hussan, and T. G. Choudhury, "Impact Of Textile Dyes Waste On Aquatic Environments And Its Treatment," Environ. Ecol, 35(3C), 2349-2353, 2017.

[16] Lowyinstitute. "In Java, the water is running out". [Internet]. 2019; Available from: https://www.lowyinstitute.org/the-interpreter/in-java-water-is-running-out

[17] E. S. Sofiyah and I. W. K. Suryawan, "Cultivation of Spirulina platensis And Nannochloropsis oculata For Nutrient Removal From Municipal Wastewater," Rekayasa, 14(1), 93-97, 2021.

[18] I. Y. Septiariva and I. Suryawan, "Development of Water Quality Index (WQI) and Hydrogen Sulfide (H2S) for Assessment Around Suwung Landfill, Bali Island," J. of Sustainability Science and Management, 2021.

[19] A. K. Nasution, N. D. Takarina, and H. Thoha, "The Presence And Abundance Of Harmful Dinoflagellate Algae Related To Water Quality In Jakarta Bay, Indonesia," Biodiversitas, J. of Biological Diversity, 22(5), 2021.

[20] A. Damar, F. Colijn, K. J. Hesse, L. Adrianto, Yonvitner, A. Fahrudin, F. Kurniawan, A.D. Prismayanti, S. M. Rahayu, B. Y. Rudianto, and A. Ramli. "Phytoplankton Biomass Dynamics in Tropical Coastal Waters of Jakarta Bay, Indonesia in the Period between 2001 and 2019," J. of Marine Science and Engineering, 8(9), 674, 2020.

[21] E. S. Sofiyah, I. Y. Septiariva, and I. W. K. Suryawan, "Domestic Wastewater Treatment Using Various Microalgae for Lipid Production," Annals of the Romanian Society for Cell Biology, 15156$15163,2021$.

[22] C. R. Holkar, A. J. Jadhav, D. V. Pinjari, N. M. Mahamuni, and A. B. Pandit, "A Critical Review On Textile Wastewater Treatments: Possible Approaches," J. of Environmental Management, Vol. 182, pp. 351-366, 2016.

[23] W. Doaemo, S. Dhiman, A. Borovskis, W. Zhang, S. Bhat, S. Jaipuria, M. Betasolo. Assessment of municipal solid waste management system in Lae City, Papua New Guinea in the context of sustainable development. Environment, Development and Sustainability, 410, 1-31, 2021.

[24] H. Hasnaningrum, B. Ridhosari, and I. W. K. Suryawan, "Planning Advanced Treatment of Tap Water Consumption in Universitas Pertamina," J. Teknik Kimia dan Lingkungan, 5(1), 1-11, 2021.

[25] H.Yin, P. Qiu, Y. Qian, Z. Kong, X. Zheng, Z. Tang, and H. Guo, "Textile Wastewater Treatment For Water Reuse: A Case Study," Processes, 7(1), 34, 2019. 
[26] N. I. Wantoputri, Q. Helmy, and S. Notodarmojo, "Textile Wastewater Post Treatment Using Ozonation," J. Presipitasi: Media Komunikasi dan Pengembangan Teknik Lingkungan, Vol. 18(1), pp. 56-63, 2021.

[27] M. Ağtaş, Ö. Yılmaz, M. Dilaver, K. Alp, and I. Koyuncu, "Hot Water Recovery And Reuse In Textile Sector With Pilot Scale Ceramic Ultrafiltration/Nanofiltration Membrane System," J. of Cleaner Production, 256, 120359, 2020.

[28] N. C. Cinperi, E. Ozturk, N. O. Yigit, and M. Kitis, "Treatment of Woolen Textile Wastewater Using Membrane Bioreactor, Nanofiltration And Reverse Osmosis For Reuse In Production Processes," J. of Cleaner Production, 223, 837-848, 2019.

[29] Z. Zhu, L. Wang, Y. Xu, Q. Li, J. Jiang, and X. Wang, "Preparation And Characteristics Of Graphene Oxide-Blending PVDF Nanohybrid Membranes And Their Applications For Hazardous Dye Adsorption And Rejection," J. of Colloid and Interface Science, 504, 429-439, 2017.

[30] I. W. K. Suryawan, I. Y. Septiariva, Q. Helmy, S. Notodarmojo, M. Wulandari, N. K. Sari, A. Sarwono, and L. Jun-Wei, "Comparison of Ozone Pre-Treatment and Post-Treatment Hybrid with Moving Bed Biofilm Reactor in Removal of Remazol Black 5,” Int. J. of Technology, 12(2), 2021.

[31] J. Liang, X. A. Ning, J. Sun, J. Song, Y. Hong, and H. Cai, “An Integrated Permanganate And Ozone Process For The Treatment Of Textile Dyeing Wastewater: Efficiency And Mechanism," J. of Cleaner Production, 204, 12-19, 2018.

[32] I. W. K. Suryawan, G. Prajati, A. S. Afifah, and M. R. Apritama, "NH3-N and COD Reduction in Endek (Balinese textile) Wastewater by Activated Sludge Under Different DO Condition With Ozone Pretreatment," Walailak J. of Science and Technology (WJST), 18(6), 9127-11, 2021.

[33] T. Shindhal, P. Rakholiya, S. Varjani, A. Pandey, H. H Ngo, W. Guo, H. Y. Ng, and M. J. Taherzadeh, "A Critical Review on Advances in The Practices and Perspectives for The Treatment of Dye Industry Wastewater," Bioengineered, 12(1), pp. 70-87, 2021.

[34] A. R. Dinçer, "Increasing BOD 5/COD Ratio of Non-Biodegradable Compound (Reactive Black 5) with Ozone and Catalase Enzyme Combination," SN Applied Sciences, 2(4), 1-10. 2020.

[35] S. Venkatesh, A. R. Quaff, N. D. Pandey, and K. Venkatesh, "Impact of Ozonation on Decolorization and Mineralization of azo dyes: Biodegradability Enhancement, By-Products Formation, Required Energy and Cost," Ozone: Science \& Engineering, 37(5), 420-430, 2015.

[36] K. Z. Abdalla and G. Hammam, "Correlation between Biochemical Oxygen Demand and Chemical Oxygen Demand for Various Wastewater Treatment Plants in Egypt to Obtain The Biodegradability Indices," Int. J. of Sciences: Basic and Applied Research, 13(1), 42-48, 2014.

[37] W. Komarawidjaja, "Peran Mikroba Aerob Dalam Pengolahan Limbah Cair Tekstil," J. Tek Ling., Vol. 8(3):223-8, 2007.

[38] M. Maharani and P. Wesen, "Degradasi Las dan Bod Dengan Proses Lumpur Aktif Menggunakan Kombinasi Bakteri Pseudomonas aeruginosa dan Pseudomonas putida," J. Envirotek, 9(2), 2018.

[39] R. Borkar, M. Gulhane, and A. J. Kotangale, "Moving Bed Biofilm Reactor: a New Perspective in Wastewater Treatment," J. Environ Sci Toxicol Food Technol, Vol. 6(6), pp., 15-21, 2013.

[40] F. D. Castro, J. P. Bassin, and M. Dezotti, "Treatment of a Simulated Textile Wastewater Containing The Reactive Orange 16 azo dye by a Combination of Ozonation and Moving-Bed Biofilm Reactor: Evaluating The Performance, Toxicity, and Oxidation by-Products. Environmental Science and Pollution Research, Vol. 24(7), pp., 6307-6316, 2017.

[41] R. Pratiwi, S. Notodarmojo, and Q. Helmy, "Decolourization of Remazol Black-5 Textile Dyes Using Moving Bed Bio-Film Reactor," In IOP Conference Series: Earth and Environmental Science, Vol. 106(1), p. 012089, IOP Publishing, 2018. 